\title{
$\mathrm{PCP}$ 処理をおこなつた雨合羽布地の耐徽力に 関する実験的研 究
}

\section{Experimental Studies on the Mildew Resistance of Clothes of Rain Coat Impregnated with Pentachlorophenol (PCP)}

\author{
久留米大学医学部衞生学・公衆衞生学教室 (主任 岡野丈雄教授) \\ 白川充 \\ Mitsuru Shirakawa \\ Department of Hygiene and Public Health, Kurume University School of Medicine \\ (Director: Prof. T. Okano)
}

\section{I. はしがき}

われわれの生活環境に生存する種々のカビ（徽）類の 寄生によつて，家具調度品，衣類，乙の他の繊維製品， あるいは光学器珹類などの污染や破損が起るととは, 看 過しえない問題であるが，殊に衣類なごの繊維製品にお いては, カビ類の寄生繁殖によつて, その材質を損傷す るのみならず, 衞生上不潔となり, かつ美的にも, また 心理的にも，好末しくない結果をもたらすととが多い。 殊に本邦のような高温多湿の梅雨期にあつては, その損 害は著しいものがある。したがつて，とのような被服類 に，防徽処理圭施してカビの寄生繁殖を防ぎ，かつ材質 の污染や破損孛防ぐことは，当然考えられねばならない ところである。

繊維類の防徽防腐剤について, 従来の研究奔検討 ${ }^{11} し$ てみると,纎維類にもつとも損害を与えるカビは, Chaetomium globosum 属属するものであるが，このカビ の寄生によつて, 繊維の抗張力 (Breaking strength) が弱められる。特に䋐緞, 帆布, 消火ホース, 砂嚢, テ ントなどは，もつとも大きな被害のある品である。

次に, 繊維類の防徽防腐削こしての必要なる条件心, 次のと括りである。すなわち（1）菌に対する毒性の大 なること，（2）低温でも有効なるここ，（3）流出性 の小なること, (4) 熱に安定, (5) 使用法が簡単,

(6) 無臭, 無毒, 無刺戟性であること, (7) 繊維類 の色調や手触りを変化させぬとと, (8) 繊維類の材質 を弱めないとと，（9）染色に悪影響がないとと，(10） 着火性を増さぬこと，(11)安価であるととなどである。 ただし, 用途によつて, 各条件の重要度は多少異なる
ととは論をまたない。

しかして，とれらの目的のために，今日実用に供され ているものは，扮招むね次のようなものである。すなお ち，有機水銀荗としての Phenylmercuric oleate (IN2555)，あるいは Pyridylmercuric oleate, stearate, ま たは acetate などがある。また Phenol 類としては, Pentachlorophenol (PCP, Dowicide 7, Santobrite) 抒 よびその 銅塩や鉛塩，2-2'-methylene bis (4-chlorophenol), Cu-quinolinolate, Salicyl anilide (de Pont 社 の “Mold Inhibitor”, I.C.I. の “Shirlan NA”), ナ フテン酸銅や同悪鉛，あるいはウンデシレン酸銅などで 葹る。

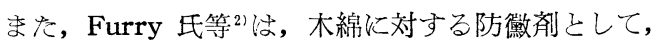
次のものが有効であつたと述べている。すなおち, Alkylated dimethyl benzyl ammonium phosphate, Salicyl anilide, o-phenylphenol, 2-chloro-o-phenylphenol' Pentachlorophenol (PCP) およびその Na 塩, Thymol +Phenyl salicylate, Chlorothymol, その他などであ る。

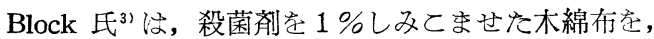
户外の日陰掞よび土中に 2 年間放置し, その抗張力の減 少率を測定し，種々の薬剤の効力を検討したが，それに よると，銅抢よび銀化合物がもつともすぐれて括り，ま た純粋な有機化合物では，Phenol 基を持つもののみが 良好なる成績を示した。特に繊維類に対する防徽効果を 薬凩処理繊維の抗張力の減少率の測定, 比較により研究 し，PCP それ自身よりも，その重金属塩の効果がもつ ともすぐれていることを明らかにした。との試験成績で は，銀塩がもつともすぐれているが，価格の点から，銅 
塭の方がもつとも実用的で，すぐれた効力を有するもの といえょう。

なお, 防水処理は, Phenol 系殺菌剤の場合には, 特 によい結果を示したと述べている。

このょうな観点から, 久留米市の某ゴム工場に拐いて 泣, 雨合羽布地中に PCP 郕を配合して, その防徽力を 期待せんとしているが，著者は，同工場で陚作された防 徽処理合羽布地の, 種々のカビ類に対する抗菌力につい て，下記のどとき実験をおてない，はなはだ興味ある成 績を得たので, 次にその概要について述べる。

な押, PCP (Pentachlorophenol, $\mathrm{C}_{6} \mathrm{Cl}_{5} \mathrm{OH}$ ) の物理化 学的諸性質, おょび細菌やカビ類に対する抗菌力につい ては, 他の関係論交 ${ }^{4-6)}$ 中に既に詳しく述べたので, 本 稿ではその説明を省略する。

\section{II. 実験材料ならびに実験方法}

本研究の主目的法, 木綿布地飞 PCP-Na 定一定量浸 みこませたものに，さらにゴム引きし，かつとれを加硫 した合羽布地材料の, 種々のカビ類に対する耐徽力を検 討するととにあるが，しかし合羽の材料になるまでには 原料布地をる綿布に種々の加工を抢てなうので, それら の各種材料のカビに対する作用をも調べるために，第 1 表のような 6 種類の材料孛試験に供した。

第 1 表 耐徽力試験に用いた材料の概要

\begin{tabular}{|c|c|c|c|c|c|c|c|}
\hline $\begin{array}{l}\text { 材料嬏 } \\
\text { 号 }\end{array}$ & $\begin{array}{cc}\text { 梦 } & \text { び } \\
\text { 質 } & \text { 構 } \\
\text { よ } & \text { 造 }\end{array}$ & 色 & $\begin{array}{r}\text { 防 } \\
\stackrel{\mathrm{P}}{\mathrm{C}} \\
\stackrel{\mathrm{P}}{\mathrm{P}}\end{array}$ & $\begin{array}{l}\text { ゴ } \\
\text { 引 } \\
\text { ま }\end{array}$ & $\begin{array}{l}\text { 加完 } \\
\text { 度 } \\
\text { 硫 } \\
\text { C }\end{array}$ & 備 & 考 \\
\hline 1 & 木 綿 布 & - & - & - & - & \multirow{3}{*}{\multicolumn{2}{|c|}{ 軽〈防水加工 }} \\
\hline 2 & $"$ & + & - & - & - & & \\
\hline 3 & " & - & + & - & - & & \\
\hline 4 & " & + & + & - & - & 同 & 上 \\
\hline 5 & $\begin{array}{l}\text { 木 綿 布 } \\
\text { ゴム引き }\end{array}$ & + & + & + & + & 同 & 上 \\
\hline 6 & $\left|\begin{array}{lll}\text { 木 } & & \text { 綿 } \\
\text { 縫 } & \text { 合 } & \text { 系 }\end{array}\right|$ & + & + & - & - & & \\
\hline
\end{tabular}

な抢，布地の染色，防徽処理の方法の概略について述 ベると，ミケスレン・カーキーB D $(95 \%)+$ トイス ン・オリーブ・グリーンB（5％）の混合染剤の $2 \%$ 溶 液で染色した綿布を, 保土ケ谷化学の PCP-Na（純度 $86 \%$ ）の1\%溶液中に通し, 次にクローム系防水剂の微 酸性塩類溶液中を通して, PCP-Na 不溶性にすると同 時に, 布地に防水性を与えたものである。

次に, 実験方法としては, Federal Standard Stock
Catalog の Section IV, Part 5 亿示された Method 5750, 5758执よび5830に準拠し，末た試験に用いたカビの菌株 以, 第 2 表に示すと㧍りで, すべて東京大学応用微生物 学研究所より分譲を受けたものである。

\section{第 2 表 実験に使用した真菌の種類}

\begin{tabular}{|c|c|}
\hline & 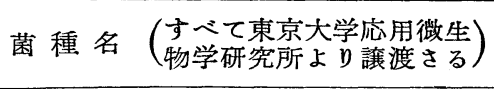 \\
\hline 1 & Aspergillus niger (ATCC 6275) \\
\hline 2 & Aspergillus niger (ATCC 9642) \\
\hline 3 & Penicillium citrinum (ATCC 9848) \\
\hline 4 & Penicillium luteum (ATCC 9644) \\
\hline
\end{tabular}

さらに, 実験方法について, その概略を述べると, 次 の 4 法になる。

\section{a) 実験 $\mathbf{I}$.}

第 2 表に示した 4 種類のカビ（子囊菌類）を，直径 9 $\mathrm{cm}$ の Petri 皿中の $4 \%$ ブドウ糖加寒天平板培地 (Sabouraud 培地) 上飞植え, $28 \sim 30^{\circ} \mathrm{C}$ の眆孚卵器内で，48時 間培養したむのの菌系执ょび胞子を，2枚のPetri 皿よ り滅菌された毛筆で掻きとり, これをあらかじめ autoclave により15pds の加圧下に $120^{\circ} \mathrm{C} て ゙ 15$ 分間高圧隇菌 した $100 \mathrm{cc}$ の蒸溜水中（100cc の三角コルベン使用） に浮遊せしめて, 菌の懸濁液(以下単に菌液と呼ぶ)学つ くる。さらに, その菌液中に, 水で充分濡れるょうに, wetting agents 老用いないで, 水中で処理したのちに速 や外室温で乾燥し, さらに autoclave 中で高圧隇菌し た 2 inches 平方の広さの被検布地の 5 種と,縫合糸 3 種 (8，40 掠よび 50 番糸で，すべて $5 \mathrm{~cm}$ の長さとする) を，それぞれ数秒間ずつ浸漬し，次にこれらを直径 $9 \mathrm{~cm}$ の Petri III中の Sabouraud 培地の中央部に配置して, $28 \sim 30^{\circ} \mathrm{C}$ の睬畉器中におさめ，48時間後の材料上のカビ の発育の有無抢るい社その程度などを検した。

\section{b) 実験 II.}

上と同様に, あらかじめ直径 $9 \mathrm{~cm} の$ Petri 皿中の培 地上に 4 種類のカビを植え $42 \sim 48$ 時間を経過した myc-

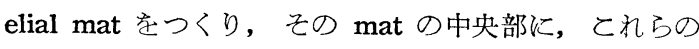
被検布地の，あらかじめ高圧滅菌抢よび乾燥されたもの を置き, さらにてれらを $28 \sim 30^{\circ} \mathrm{C} の$ 睜卵器内にて培盖し て, 48時間後のカビの発育の有無を検した。

\section{c) 実験 III の (1)}

あらかじめ被検布地を 5 枚ずつ $500 \mathrm{cc} の$ 三角コルベン 中に入れ, その容積の 水が 1 時間に 5 回入れかわる速 度に調節された水道流水で, 24 時間連続水洗し, 水洗終 
了後, 高圧滅菌せる被検材料を, 実験 I と同要領で, 菌 液中に数秒間浸漬して, しかるのちに Sabouraud 培地 上に配置して，48時間培養後のカビの発育の有無を検し た。

\section{d) 実験 III の (2)}

実験 IIIの（1）と同様に処理した水洗布地を，実験 II と同様の mycelial mat 上の中央部に置いて, その布 地上のカビの発育の有無学検した。

な㧍, とれらの試験に当つては, 被験材料はすべて 5 枚を 1 組として各種の実験を抢てない，その試験成績を 総合判断することにした。

次に, これらの耐徽力試験終了後, カビに曝露した被 検材料は, すべて菌の発育の有無の判定後直ちに水洗 し, かつ室温で乾燥後, 抗張力, または破壊強度試験 (Breaking strength test) をおてつなた。この検査は, 前記ゴム工場研究部において, 島津製抗張力検查機を用 いて, 室温 $28^{\circ} \mathrm{C}$, 気湿 $61 \%$ の条件のもとに抬となわれた むのである。

Breaking strength の変化の求め方は次の式により, 数值は\%で示されるが, 本值が1\%以下であれば,

$$
\frac{\mathrm{O}-\mathrm{E}}{\mathrm{O}} \times 100
$$

ただし $\mathrm{O}$ ： カビに曝露する前の值 $(\mathrm{kg})$ $\mathrm{E}$ ： カビに曝露した後の值 $(\mathrm{kg})$

Breaking strength は㴽とんど失われていず，したがつ て材質のカビによる損傷は湶とんぞないと判定されるも のである。

\section{III. 実験成績}

以上のでとくして得られた実験成績は, 各試験方法に 従つて記載し, 亦つ理解を容易ならしめるために, ある ものは写真をもつて示すととにした。

\section{a) 実験 I の成績}

第 3 抢よび 4 表, ならびに写真A 力試験成績を要約すれば, 被検材料 No. 1 (非染色, 非 防徽処理の木綿布地で, 対照となるもの) は, すべて布 地上のみならず，その周囲の培地上にも，カビの著明な る発育を認め, カビに対する抗菌力はまつたく認められ なかつた。

No. 2 (染色, 非防徽処理材料) の布地に执いては, 前者同様に，布地上抢よびその周囲培地上に，カビの著 しい発育をみるが，中には発育を惊とんぞ認めないもの もあり，乙れ㭠色剤の抗菌力によるものと考えられ
る。

No. 3 (防徽処理のみの材料) に执いては，潘とんぞ すべての布地に㧊いて，カビの発育を認めないが，中に 注布地の片隅の部分に, 僅かに菌糸の発育を及ることが ある。これは菌液浸漬時に, 綿布の周辺部に, 胞子や菌 糸の濃厚な部分が多量に付着した結果，培地上に菌の発 育定容ならしめたものと考えられる。

No. 4 (染色, 防徵処理材料) に执いても, No. 3 の 材料之潘济同様の結果を示しているが，No. 3 に比べる と，いくらか菌の発育の程度も弱く，したがつてNo. 4 の方が抗菌力はすぐれているようである。

次に，染色，防徽，コム引き，さらに約 $140^{\circ} \mathrm{C}$ 熱を 加えて加硫を抢てなつた，合羽布地としての最終材料て あるNo. 5 では，ゴム部の表面にも，また綿布の表面に も，まつたく菌の発育を認めず，ただ材料の周囲に付着 した菌液中の菌糸や胞子が，材料周囲の培地上に発育し ているのが認められた。

No. 6 の, 縫合糸たる $8 ， 40$ おび 50 番の各糸におい ては, 8 番糸に Pen. lut. の及発育专さず，その他の 菌種に执いて蛜，全糸に菌の発育が認められた。このと

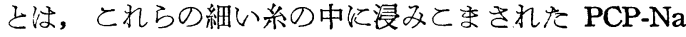
の有效濃度が，菌の発育を抑制する量に足りないためと 思われる。

\section{b）実験 II の成綪}

第 3 および 5 表に示されるごとく(写真省略), mycelial mat 上に招かれた試験材料では，その表面に菌が 発育するととは概して困難のょうで，Aspergillus 抢よ び Penicillium の培地中に分泌した黒褐色あるいは橙黄 色の色素が, 各布地中に浸透し, 着色するのが㤍められ た。そして, 材料 No. 1 より No. 6 亿至るまで, 布地 の表面に浊，㴽とんどすべてに菌の発育は認められなか つた。

\section{c）実験 III の（1）の成緌}

第 3 捛よび 6 表，ならびに写真 $\mathrm{B}$ に示されるごとく， 24 時間水洗後の耐徽力の消長を検すると, No. $1 \sim 3$ の 材料においては，実験 I の成績と比較して，すべての菌 の著しい発育を認め, 水洗による効力の減退を知ること ができる。しかし No. 4 に扮いては，材料の中央部に ほ菌の発育は みられず，周辺部の 久に菌の発育を認め る。したがつて，No. 4 の材料では，布地の周囲よりの 薬成の流失が考えられるが，しかし水洗によつても，な 执かなりの効力を保有していることがわかる。

No. 5 の材料では, ゴム部にも, 布地上にも, まつた く菌の発育は認められなかつた。 
第 3 表 菌の発育の有無あるいはその程度

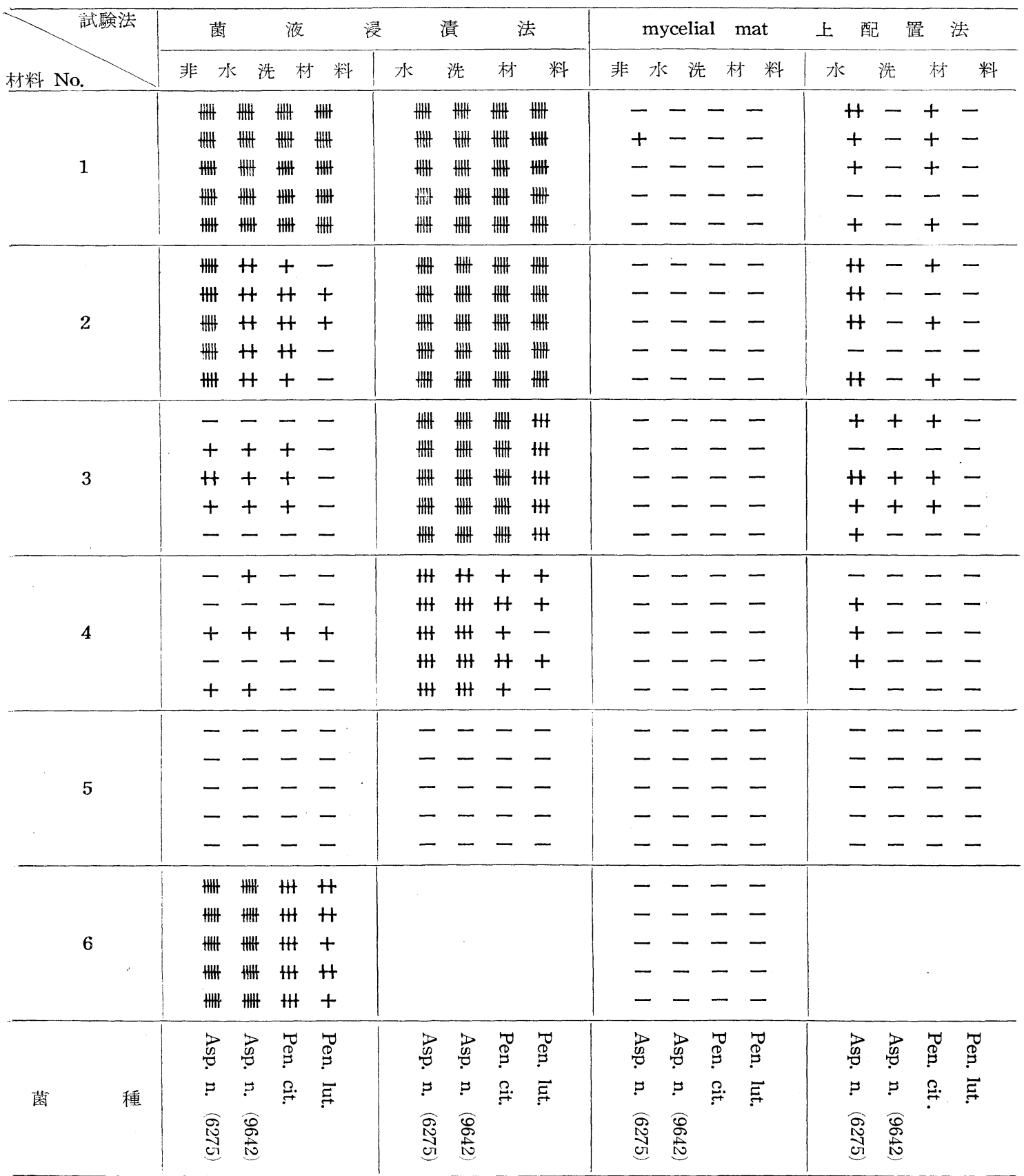

\section{d）実験 III の（2）の成績}

第 3 扎よび 7 表に示すどとく（写真省略），水洗 24 㭙 間の材料のNo. 1 3 K捛いて蛒，一部に菌の軽度の発 育字示すものがあるが，その他の菌登育を示さなかつ た。
No. 4 でね, Asp. nig. (6275) の軽度の発育を認める ものもあつたが, 概して本材料では, 菌の発育は䜑めら れなかつた。

No. 5の材料では, ゴム部にも, 布地上にも, こもに 菌の発育はまつたく認められなかつた。 
第 4 表 実験 I における抗菌力試験の概要

\begin{tabular}{|c|c|c|c|c|c|}
\hline \multicolumn{2}{|c|}{$\begin{array}{l}\text { 材 料 } \\
\text { No. } \\
\left(\begin{array}{l}5 \text { 枚 } \\
1 \text { 組 }\end{array}\right)\end{array}$} & Asp. nig. (ATCC 6275) & Asp. nig. (ATCC 9642) & Pen. cit. (ATCC 9848) & Pen. lut. (ATCC 9644) \\
\hline \multicolumn{2}{|c|}{1} & $\begin{array}{l}\text { 菌の著しい発育が布面上 } \\
\text { にみ, } \\
\text { ているが, 布地の周わ柬培 } \\
\text { 地上には白色の菌系の発 } \\
\text { 育著明なり。 }\end{array}$ & $\begin{array}{l}\text { 布面上に黒色の菌糸扔よ } \\
\text { び胞子の発育とがみ } \\
\text { れ, 周囲培地上にも白色 } \\
\text { の菌系と黒色の胞子の発 } \\
\text { 生がみられれる。 }\end{array}$ & $\begin{array}{l}\text { 布面上に白色の菌の発育 } \\
\text { 著しく，さらに周囲培地 } \\
\text { 土にも及ぶ。 }\end{array}$ & $\begin{array}{l}\text { 布面上に白色の菌の著明 } \\
\text { なる発育をきたし, 周 } \\
\text { 培地上に及ぶ。 }\end{array}$ \\
\hline \multicolumn{2}{|c|}{2} & $\begin{array}{l}\text { 布面上に白色あるいは黒 } \\
\text { 色の菌の発を認め,さ } \\
\text { らに周囲の培地上にも菌 } \\
\text { 糸の発育が及んでいる。 }\end{array}$ & $\begin{array}{l}\text { 布面上にはをいして菌の } \\
\text { 発育はみれないが, 布 } \\
\text { 地の四隅の部分に多少菌 } \\
\text { の発育を認める。 }\end{array}$ & $\begin{array}{l}\text { 布面上には菌の発育はほ } \\
\text { とんど認められいが, } \\
\text { 一部には発育をみるもの } \\
\text { むある。 }\end{array}$ & $\begin{array}{l}\text { 布地上K菌の発育を認め } \\
\text { ぬむのが多いが, 多毟 } \\
\text { 育するものも認めら和る }\end{array}$ \\
\hline \multicolumn{2}{|c|}{3} & 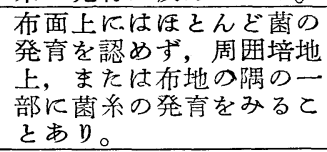 & $\begin{array}{l}\text { 布面上にはときにその隅 } \\
\text { の部に菌系の発育を認 } \\
\text { めるも, 大部分は発育を } \\
\text { 認めず。 }\end{array}$ & $\begin{array}{l}\text { 布面上にはとをにその隅 } \\
\text { の一部に菌系の発育を認 } \\
\text { めるす, 大部分は発育を } \\
\text { 認めず。 }\end{array}$ & $\begin{array}{l}\text { 布面上扎よび周囲培地上 } \\
\text { に菌系の発育をまつたく } \\
\text { 認めない。 }\end{array}$ \\
\hline \multicolumn{2}{|c|}{4} & $\begin{array}{l}\text { 布面上扎よび周囲にはほ } \\
\text { れど菌の発育は認めら } \\
\text { れずとをに布地の隅の } \\
\text { 部分に白色の菌系の発育 } \\
\text { するものあり。 }\end{array}$ & $\begin{array}{l}\text { 布面拒よび周囲培地上に } \\
\text { ほとんど菌の発育を認め } \\
\text { ず。 }\end{array}$ & $\begin{array}{l}\text { 布面および周囲培地上に } \\
\text { ほとど菌の発育を認め } \\
\text { ず。 }\end{array}$ & $\begin{array}{l}\text { 布面扔よび周囲培地上に } \\
\text { ほとんど菌の発育を認め } \\
\text { ず。 }\end{array}$ \\
\hline \multirow{2}{*}{5} & 下 & $\begin{array}{l}\text { ゴム布上は菌の発育をま } \\
\text { つたく認めないが, 周囲 } \\
\text { 培地上には多少の発育が } \\
\text { みられる。 }\end{array}$ & $\begin{array}{l}\text { ゴム布上は菌の発育をま } \\
\text { つたく認めないが, 周囲 } \\
\text { 培地上には多少の発育が } \\
\text { みられる。 }\end{array}$ & $\begin{array}{l}\text { ゴム布上は菌の発育をま } \\
\text { つたく認めないが, 周囲 } \\
\text { 培地上には多少の発育が } \\
\text { みられる。 }\end{array}$ & $\begin{array}{l}\text { ゴム布上は菌の発育をま } \\
\text { つたく認めないが，周囲 } \\
\text { 培地上には多少の発育が } \\
\text { みられる。 }\end{array}$ \\
\hline & $\begin{array}{l}\text { 布 } \\
\text { 上 }\end{array}$ & $\begin{array}{l}\text { 布面上には菌の発育はま } \\
\text { つた認められないか， } \\
\text { 周囲培地上には多少の菌 } \\
\text { の発育が認められる。 }\end{array}$ & $\begin{array}{l}\text { 布面上には菌の発育はま } \\
\text { つたく認めれないが, } \\
\text { 周囲培地上には多少の菌 } \\
\text { の発育が認められる。 }\end{array}$ & $\begin{array}{l}\text { 布面上には菌の発育はま } \\
\text { つたく認められいが, } \\
\text { 周囲培地上には多少の菌 } \\
\text { の発育が認められる。 }\end{array}$ & $\begin{array}{l}\text { 布面上には菌の発育はま } \\
\text { つた認められない゙, } \\
\text { 周囲培地上には多少の菌 } \\
\text { の発育が認められる。 }\end{array}$ \\
\hline \multicolumn{2}{|r|}{6} & $\begin{array}{l}\text { 糸上に白色の菌糸の発育 } \\
\text { 著しく，周囲に及ぶ。 } \\
\text { 番糸では多少その程度は } \\
\text { 小さい。 }\end{array}$ & 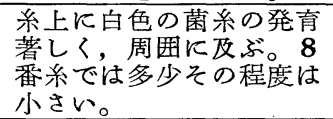 & 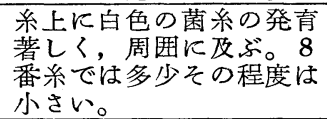 & $\begin{array}{l}8 \text { 番糸上には菌の発育に } \\
\text { そん゙な゙, 他の糸でも } \\
\text { 割合に菌の発育な少な。 }\end{array}$ \\
\hline
\end{tabular}

第 5 表 実験 II における抗菌力試験の概要

\begin{tabular}{|c|c|c|c|c|c|}
\hline \multicolumn{2}{|c|}{$\begin{array}{l}\text { 材 料 } \\
\text { No. } \\
\left(\begin{array}{l}5 \\
\text { 枚 } \\
1\end{array}\right)\end{array}$} & Asp. nig. (ATCC 6275) & Asp. nig. (ATCC 9642) & Pen. cit. (ATCC 9848) & Pen. lut. (ATCC 9644) \\
\hline \multicolumn{2}{|c|}{1} & 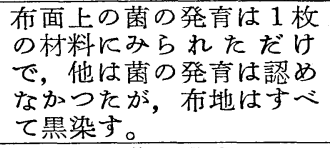 & $\begin{array}{l}\text { 布地上に菌の発育なく, } \\
\text { 布地の黑染著し。 }\end{array}$ & $\begin{array}{l}\text { 布地上に菌の発育は認め } \\
\text { られない゙，布地はすざ } \\
\text { て黄染す。 }\end{array}$ & $\begin{array}{l}\text { 布地上に菌の発育は認め } \\
\text { られないが, 布地はすべ } \\
\text { て黄染す。 }\end{array}$ \\
\hline \multicolumn{2}{|c|}{2} & $\begin{array}{l}\text { 布地上に菌の発育をまつ } \\
\text { たく認めず。 }\end{array}$ & $\begin{array}{l}\text { 布地上に菌の発育をまつ } \\
\text { たく認めいが, 布地は } \\
\text { 著しく黒染す。 }\end{array}$ & $\begin{array}{l}\text { 布地上に菌の発育をまつ } \\
\text { たく認めず。 }\end{array}$ & $\begin{array}{l}\text { 布地上に.菌の発育をまつ } \\
\text { たく認めず。 }\end{array}$ \\
\hline \multicolumn{2}{|r|}{3} & $\begin{array}{l}\text { 布地上に菌の発育はまつ } \\
\text { たく認めないが, 布地は } \\
\text { 多少黑染す。 }\end{array}$ & $\begin{array}{l}\text { 布地上に菌の発育をまつ } \\
\text { たく認めないが，布地は } \\
\text { 著しく黒染す。 }\end{array}$ & $\begin{array}{l}\text { 布地上に菌の発育をまつ } \\
\text { たく認めず。 }\end{array}$ & $\begin{array}{l}\text { 布地上に菌の発育をまつ } \\
\text { そく認めず, 布地は多少 } \\
\text { 黄染す。 }\end{array}$ \\
\hline \multicolumn{2}{|r|}{4} & $\begin{array}{l}\text { 布地上に菌の発育をま口 } \\
\text { たく認めず。 }\end{array}$ & $\begin{array}{l}\text { 布地上に菌の発育をまつ } \\
\text { たく認めず。 }\end{array}$ & $\begin{array}{l}\text { 布地上に菌の発育をまつ } \\
\text { たく認めず。 }\end{array}$ & \begin{tabular}{|l} 
布地上に菌の発育をまつ \\
たく認めず。
\end{tabular} \\
\hline \multirow[b]{2}{*}{5} & 布 & $\begin{array}{l}\text { ゴム部上面に菌の発育を } \\
\text { まつたく認めず, 黒染も } \\
\text { まつたく認められない。 }\end{array}$ & $\begin{array}{l}\text { ゴム部上面に菌の発育を } \\
\text { まつたく認めず, 黒染も } \\
\text { まつたく認められない。 }\end{array}$ & $\begin{array}{l}\text { ゴム部上面に菌の発育をま } \\
\text { つたく認めず，が黄染も } \\
\text { まつたく認めろない。 }\end{array}$ & \begin{tabular}{|l} 
ゴム部上面に菌の発育をむ \\
つたく認めず，かつ黄染も \\
まつたく認められない。
\end{tabular} \\
\hline & 上 & $\begin{array}{l}\text { 布地上に菌の発育をまつ } \\
\text { く認めず,かつ布地の } \\
\text { 黒染もまつれく認められ } \\
\text { ない。 }\end{array}$ & $\begin{array}{l}\text { 布地上に菌の発育をまつ } \\
\text { たく認めず, かつ布地の } \\
\text { 黒染むまつたく認められ } \\
\text { ない。 }\end{array}$ & $\begin{array}{l}\text { ゴム部上面に菌の発育を } \\
\text { まつたく認めず, 代黄 } \\
\text { 染もまつたく認められな } \\
\text { い。 }\end{array}$ & $\begin{array}{l}\text { ゴム部上面に菌の発育を } \\
\text { まつたく認めず, かつ黄 } \\
\text { 染もまつたく謋められな } \\
\text { い。 }\end{array}$ \\
\hline \multicolumn{2}{|r|}{6} & $\begin{array}{l}\text { 糸上に菌の発育を認めず } \\
\text { 多少糸の黒染は認められ } \\
\text { る。 }\end{array}$ & $\begin{array}{l}\text { 糸上に菌の発育を認めず } \\
\text { 多少系の黒染は認められ } \\
\text { る。 }\end{array}$ & $\begin{array}{l}\text { 系上に菌の発育をまつた } \\
\text { く認めず, 糸の黄染もみ } \\
\text { られない。 }\end{array}$ & $\begin{array}{l}\text { 系上に菌の発育をまつた } \\
\text { く認めず, 系の黄染もみ } \\
\text { られない。 }\end{array}$ \\
\hline
\end{tabular}


第 6 表 実験 III（1) における抗菌力試験の概要

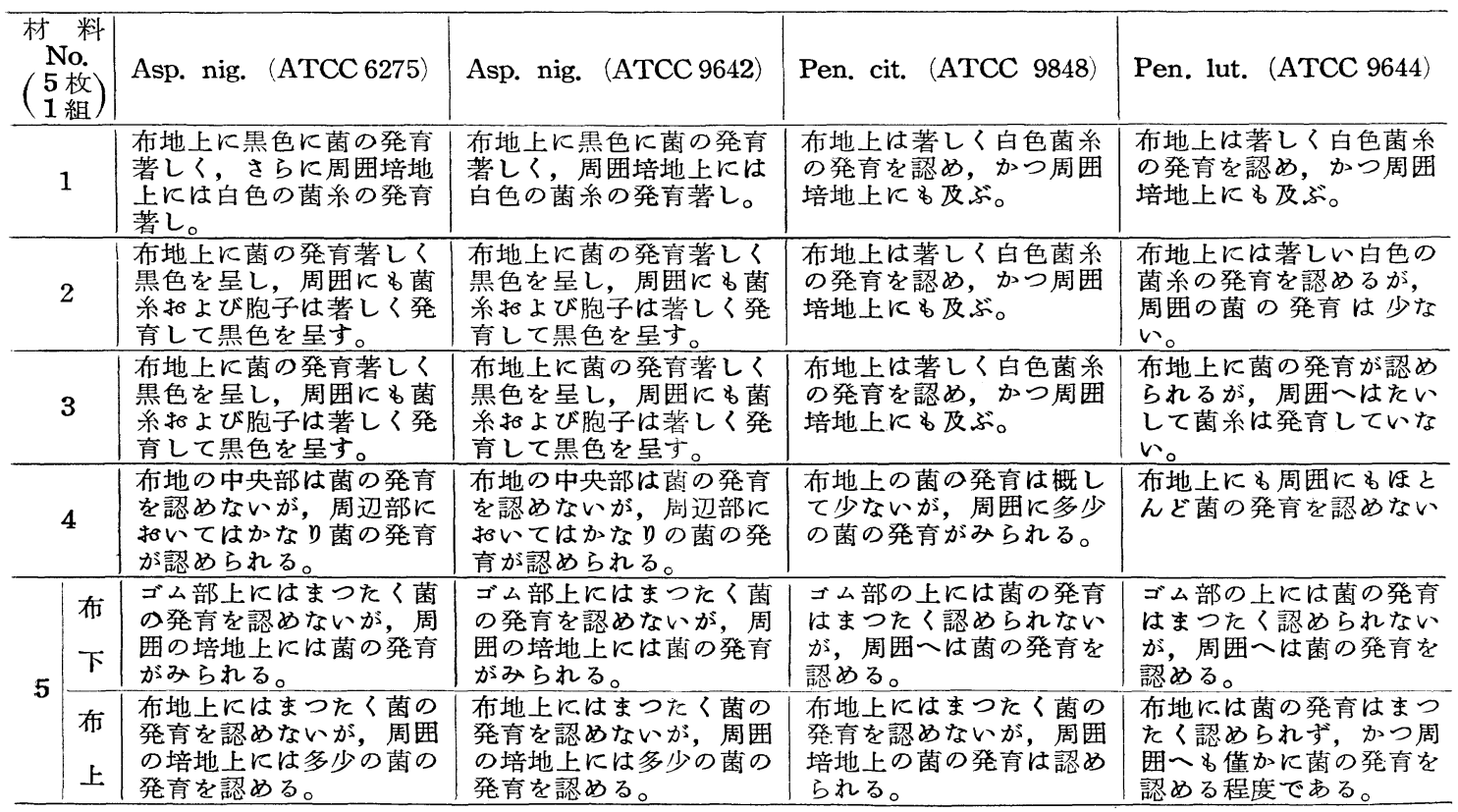

第 7 表 実験 $\operatorname{III}(2)$ における抗菌力試験の概要

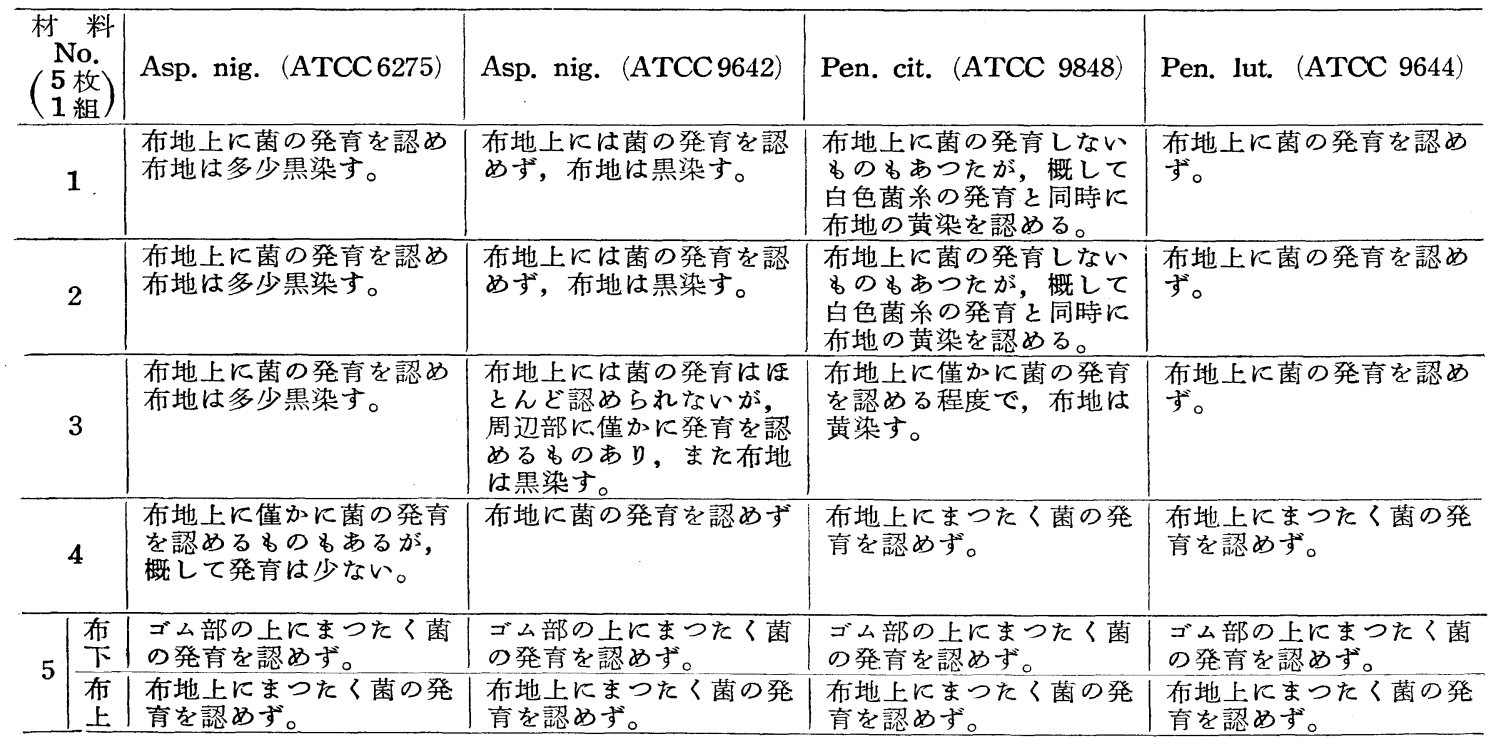

次に, これらの菌に曝露された材料は, 菌の発育の有 無の判定後, 直与飞水洗, 乾燥後, 抗張力試験を抢とな 小, 次の諸測定値が得られた。
(1) Control
$25.9 \mathrm{~kg}$
(口). 実験 I 使用後の材料
$28.7 "$
(八) 実験 II 使用後の材料.
$30.9 "$
（二） 実験 III（1）使用後の材料

\section{（ホ）実験 III（2）使用後の材料 $29.5 \mathrm{~kg}$}

これらの実験使用後の各材料の抗張力は, 対照に比 し逆に大となつている。菌に曝露され湿潤するととによ り，被検材料たる布地の抗張力が增大寸るとは考元られ ないが，耐徽力試験を経るととに上り，綿布の織系の不 均等性や湿度なぞの影響なぞのために乾燥後収縮をきた し, そのために単位面積あたりの経緯糸の数が増加し, 
かえつて原布よりも抗張力が増加したあのと思われる。 したがつて, との点についてはさらに厳密なる検討を要 するが, 本検查の場合, 数值的には, 抗張力の減退は示 されなかつた。

\section{IV. 総括ならびに考按}

以上の実験成績を総括し, かつ要約してみると, 次の どとくなる。

まず菌液浸漬法においては, 染色も防徽処理も施して ない綿布（No. 1) は，24時間水洗材料は勿論, 非水洗 材料でも, ともに著明なる菌の発育が認められ, 綿布の みの抗菌力は皆無であつた。

染色の夕の材料 (No. 2) では, 非水洗, 水洗の両 方とも, 布地上に菌の発育をかなり著明に認めたが, 非 水洗材料の中には, No. 1 に比べて菌の発育が弱いもの もあり, 染色郕による抗菌力の結果ではないかと考えら れる。

PCP 防徽処理を施された材料 (No. 3 ) では, 非水 洗時には, 菌の発育は潘をんど認められがたくなり, 相 当の抗菌力を有しているととが知られるが，24時間水洗 の結果は, その抗菌力もほとんど消失して, 著明なる菌 の発育を示した。

染色ならびに防徽処理の No. 4 の材料では, No. 3 と 活ぼ同样の成績を示しているが, 非水洗招よび水洗の両 方上も, No. 3 に比べると, 菌の発育はかなり弱く, 染 色おょび防徽処理による効果が，かなりはつきりと認め られるょうである。

次に, No. 5 の合羽布地は, 非水洗, 水洗の両材料之 も，いずれの菌の発育も認められず，抗菌力はまず完全 であつた。

縫合系 No. 6 では, PCP 処理を施されている以上, 多少とも抗菌力を有しているはずであるが，本法による 試験では, その抗菌力は充分発揮されなかつた。しかし $\mathrm{PCP}-\mathrm{Na}$ の含有量に相応した菌量によつて試験を捛てな えば, 糸にもそれ相当の抗菌力以認められるものと思わ れる。

次に, mycelial mat 上配置法によつては, 非水洗恍 料は勿論, 水洗材料に执いても，概して材料上の菌の発 育は困難のようで, 本法による抗菌力の観察はあまり期 待できない。しかし，菌に曝露された材料の抗張力を調 べるためには, 本法は必要な試験である。

\section{V. 結論}

PCP-Na による防徽処理のゴム引き雨合羽布地の, 4
種のカビ (Aspergillus niger (ATCC 6275㧍よび9642)) ならびに Penicillium citrinum et luteum (ATCC 9848 および9644）に対する耐徽力について，これらの菌の䀣 濁夜中浸漬法ならびに mycelial mat. 上配置法にょつ て, 種くの対照材料と比較実験をおこない, 次のような 成績を得た。

1）まつたくなんらの処理も施してない木綿布地飞执 いては, 非水洗, 水洗の別を問わず, すべてに菌の著し い発育があり,なんらの抗菌力も認められない。

2）染色布地，PCP-Na による防徽处理布地扢よび 染色防徽処理布地などでは, 非水洗時には, 同溙に菌の 発育が若干認められるものもあるが, まつたく無処理の 布地に比べれば, 菌の発育の程度ははるかに弱く, した がつてこれらはかなりの抗菌力を有するものといえよ う。しかし, その効力も水洗後はかなり低下することが 示された。

3）染色, 防徽, ゴム引き, さらに䄪 $140^{\circ} \mathrm{C}$ 熱を加 えて加硫された合羽布地に扮いては, 非水洗, 水洗の両 方とす, 菌の発育をまつたく認めず, 完全なる抗菌力を 有することが示された。

4) 縫合糸 $(8,40,50$ 番糸) は, 染色抢よび防徽処理を 批されているが, 菌液の濃度が高すぎるために, 抗菌力 は充分発揮されず, 糸の表面には著明なる菌の発育が示 された。

5） mycelial mat 上配置法による抗菌力試験に抢い ては，各材料とも布地上に菌の発育を認めるととは概し て困難であつた。

6) さらにこれらのカビに曝露された各種の試験材料 について, 抗張力試験 (Breaking strength test) を拉 こなつたが, 対照よりもその減弱を示すものはなく, 材 質の損耗は認められはかつた。

以上の実験成績により, PCP-Na 用いて防徽処理を 施した雨合羽材料たるゴム引き布地は, 供試 4 種のカビ 類に対して, 完全にすぐれた耐㣲力を有しているという ことができる。

本稿の要旨は, 昭和 32 年 7 月 10 日, 第 27 回日本衛生 学会総会で発表した。

稿を終るに当り，御校閲を戴いた岡野教授ならびに 貴重なる実験材料を御提供下されれ日本ゴム株式会社， 扣よび貴重なる試験菌株の御分譲を賜わつた東京大学 応用微生物学研究所に対し, 深甚の謝意を表する。 
写真 $\mathbf{A}($ その 1)。各種の非水洗材料の菌液浸清法（実験 I）による抗菌力成辕

菌株 Aspergillus niger

材料No.

(6275)

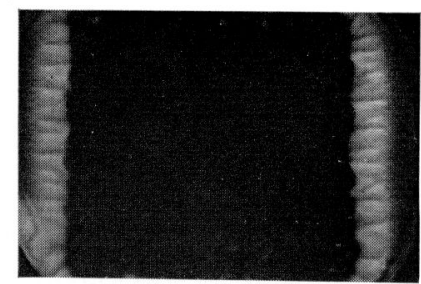

2

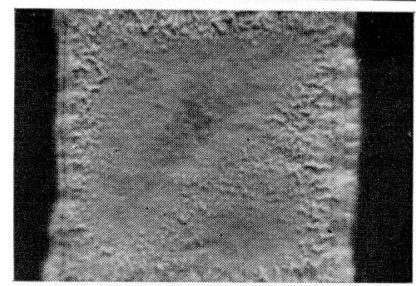

3

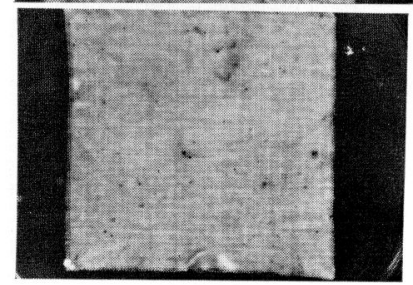

4
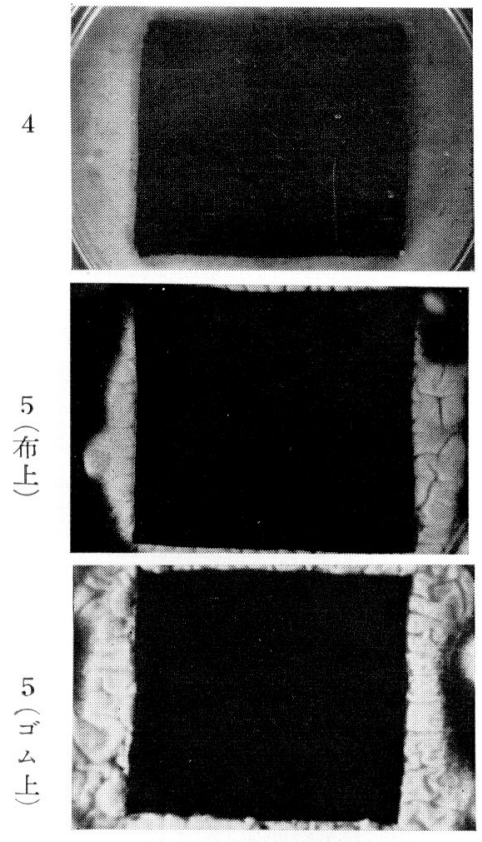

6

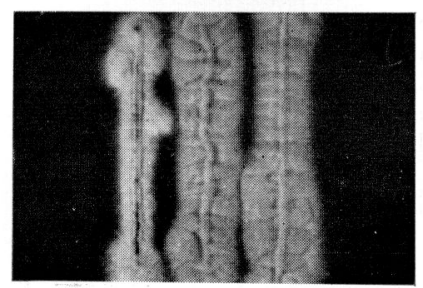

Aspergillus niger (9642)
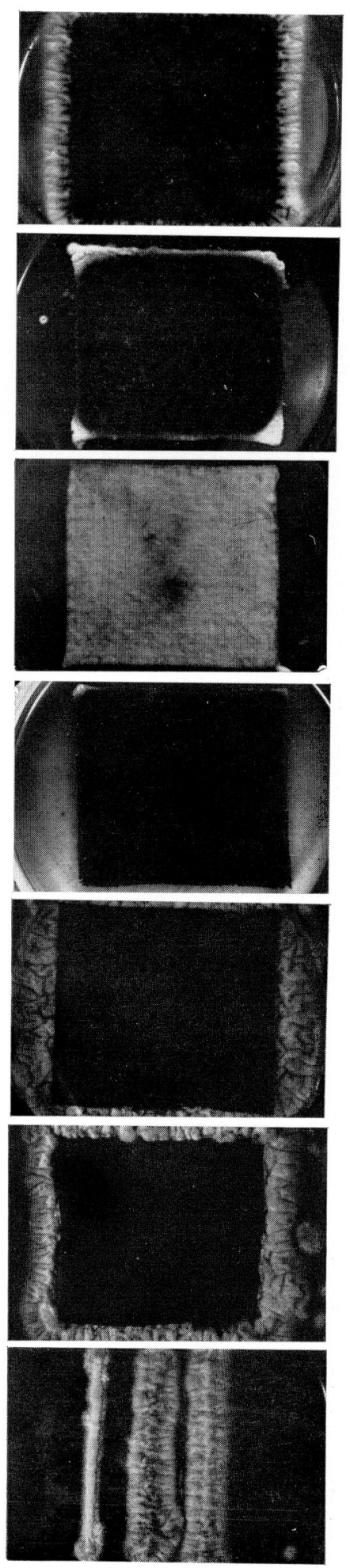

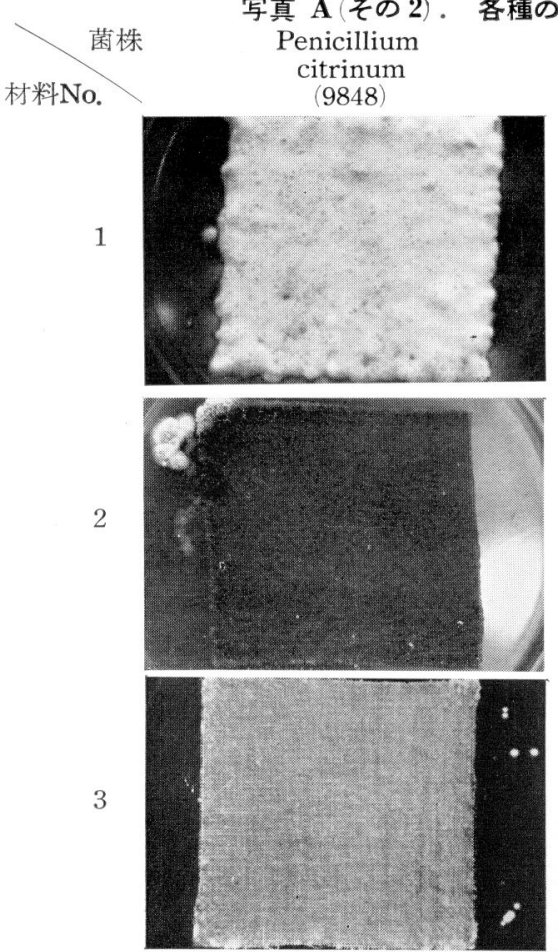

4
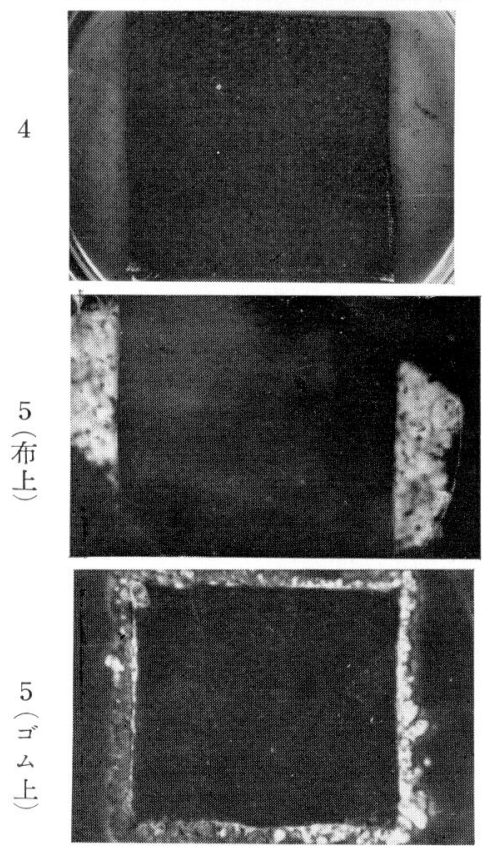

6

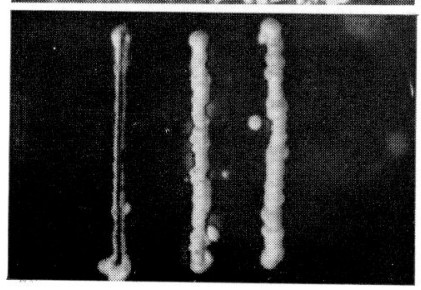

による抗菌力成綪

Penicillium

luteum
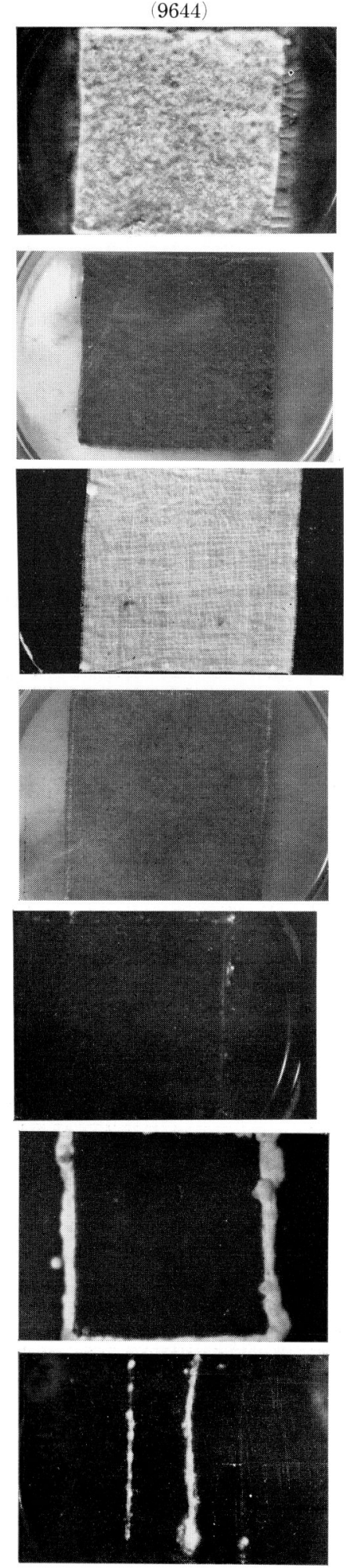
写真 $\mathrm{B}($ その 1)。各種の 24 時間水洗材料の菌液浸清法（実験 III の $(1)$ ）による抗菌力成綪
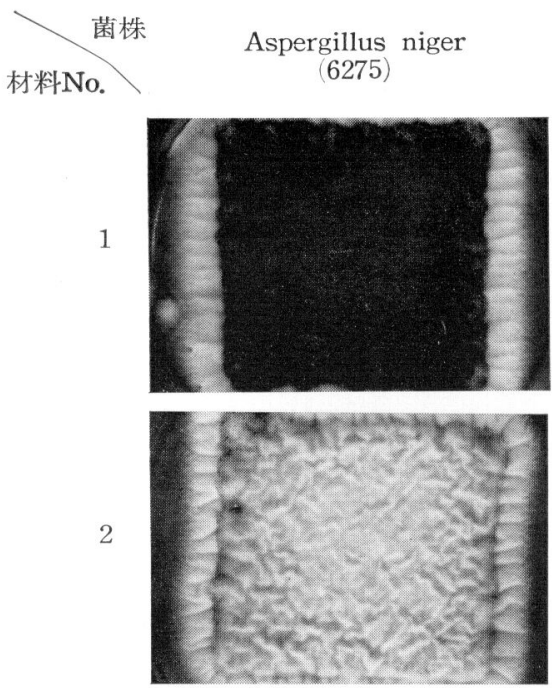

3

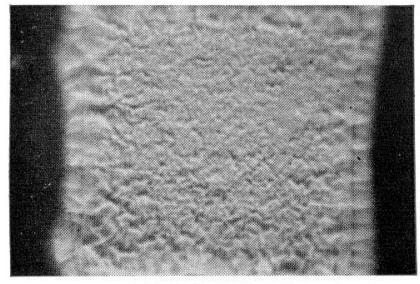

4
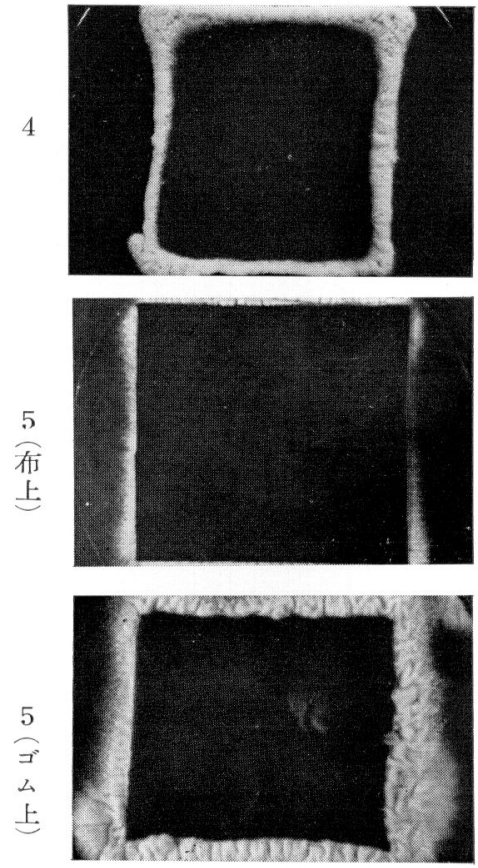

Aspergillus niger (9642)
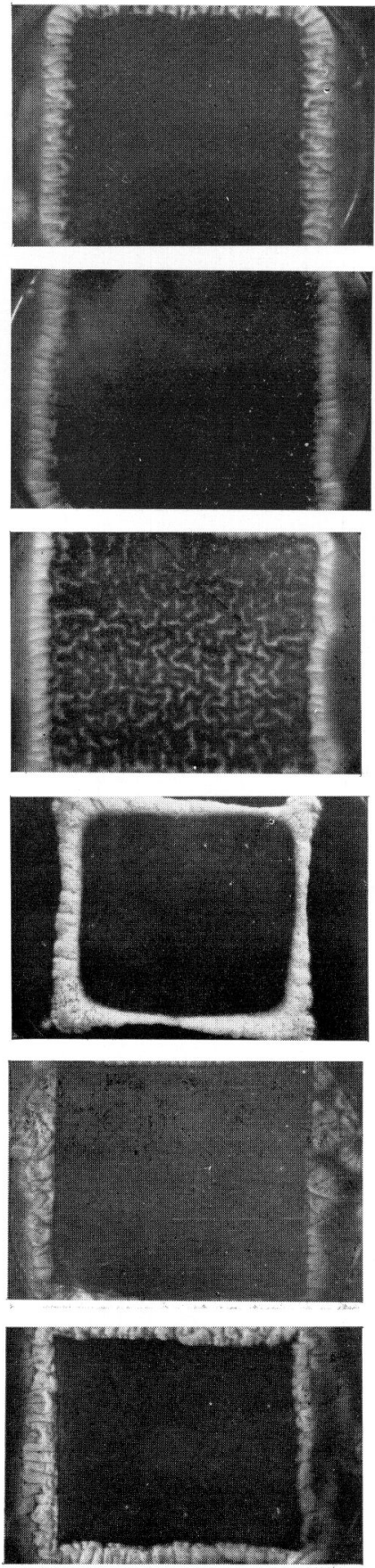
写真 $\mathrm{B}($ その 2). 各種の 24 時間水洗材料の菌液浸清法（実験 III の（1））による抗菌力成績

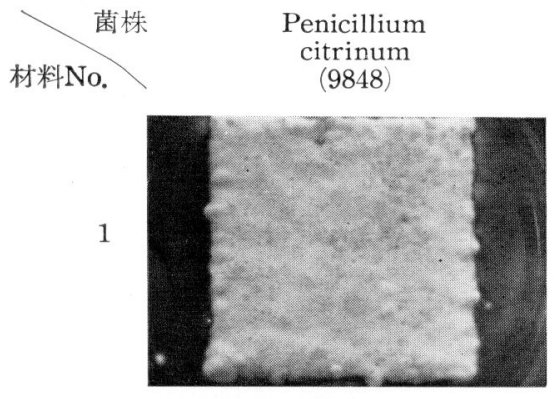

Penicillium

luteum

(9644)

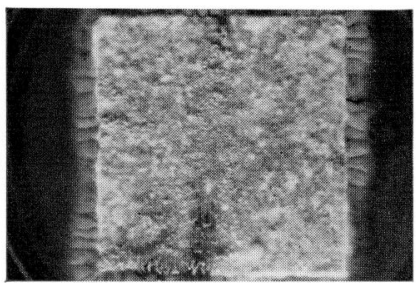

2
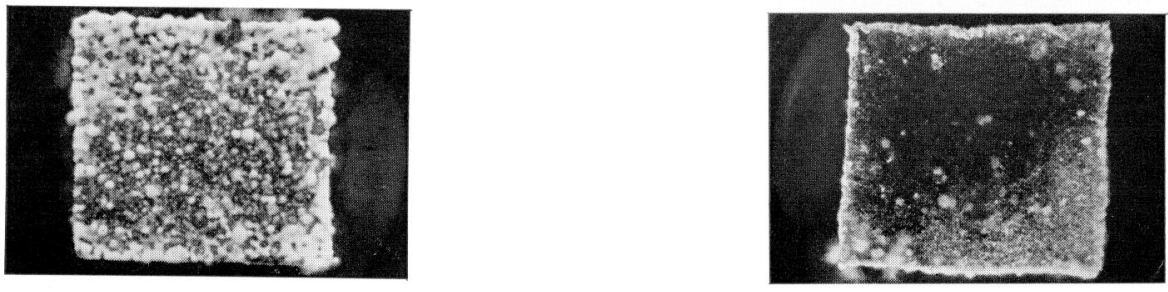

3
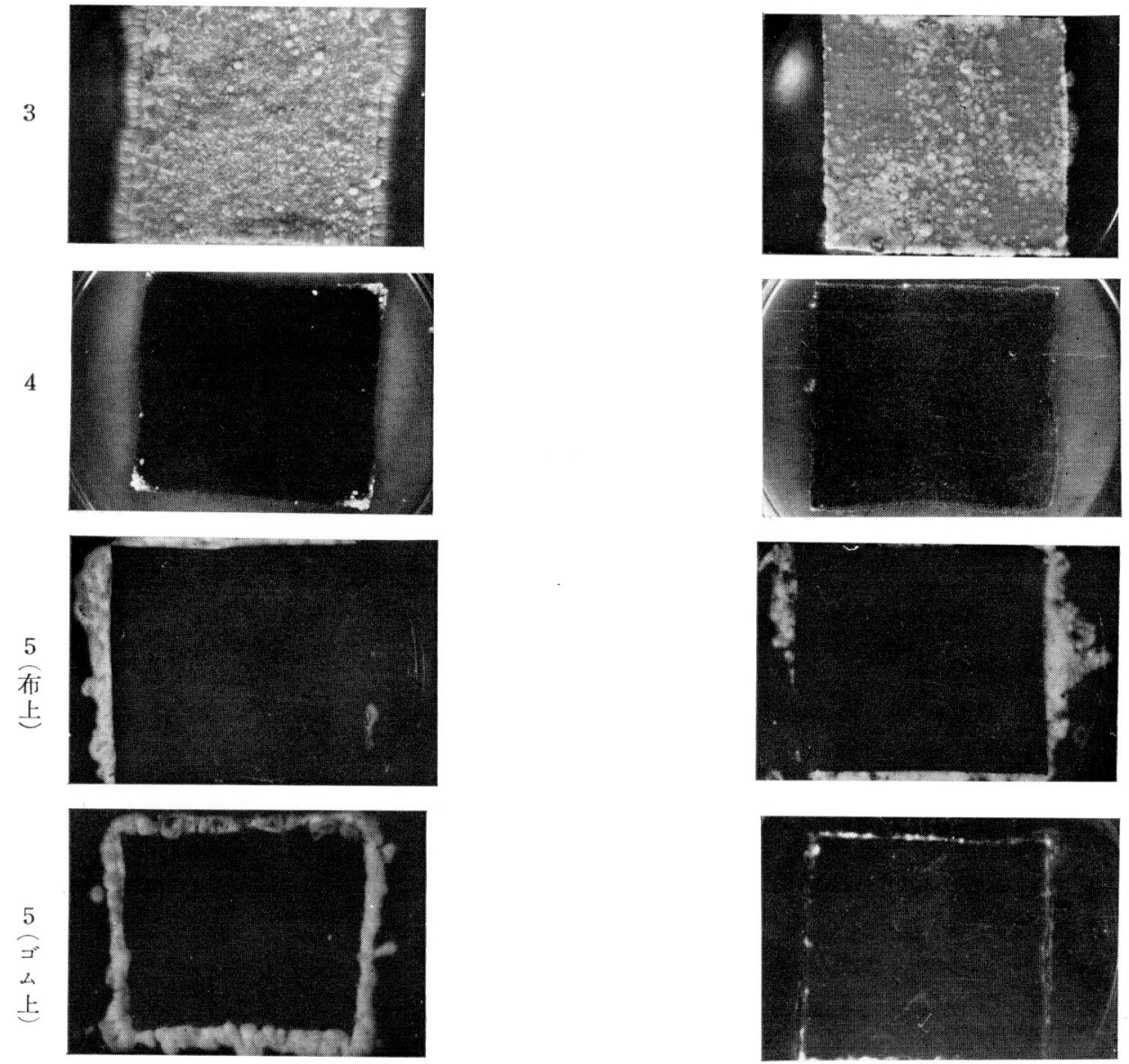


\section{参考文献}

1)太田暢人：合成殺虫 - 殺菌・除草剂，176，215, 技報堂, 昭27.

2) Furry, M. S., Robinson, H. M. \& Humfeld, H. : Ind. Eng. Chem., 33 : 538, 1941.

3) Block, S. S. : Ind. Eng. Chem., 41 : 1783, 1949.

4) 白川 充他：医学々生物学, 38（5）: 147〜 151,
昭 31；日本衞生学雑誌, $10 （ 4): 197 \sim 210$, 昭 31 .

5）白川 充他：医学々生物学, 40 (4) : 162 167, 昭 31 ; 日本衛生学雑誌, 11 (3) : 143 157, 昭 31.

6) 白川 充：医学々生物学 (受付済); 日本衞生学 雑誌, 12 (5) : 313 320, 昭32.

（受付： 1957 年 11 月 15 日） 